ISBN 978-93-84422-85-1

11th International Conference on Chemical, Agricultural, Biological and Environmental Sciences

(CABES-2018)

April 17-18, 2018 Kyoto (Japan)

\title{
Utilitation of Milk Package Waste as Source of Poly Aluminium Chloride (PAC) Coagulant for Purification of Peat Water
}

\author{
Rita Susanti $^{1 *}$, Muhdarina $^{2}$ and Tengku Ariful Amri ${ }^{3}$ \\ ${ }^{1 *}$ Bogor Agricultural University, Bogor, West Java, Indonesia \\ ${ }^{2}$ Material Science laboratory, department of Chemistry, Faculty of mathematical and Natural Sciences, \\ University of Riau, Indonesia \\ ${ }^{3}$ Environmental Assessment Center, Faculty of Mathematical and Natural Science, \\ University of Riau, Indonesia
}

\begin{abstract}
Milk package waste can be found in our environment. This waste can be utilized to synthesis liquid coagulant was Poly Aluminum Chloride (PAC). The method that using to synthesis PAC coagulant are partial hydrolysis and polymerization. PAC coagulant was characterized based on SNI 06-3822-1995 and functional group was characterized by Fourier Transform Infra-Red (FTIR). Performance of PAC coagulant was tested to purification of peat water by using coagulation and flocculation process. PAC coagulant can removed of smelling, color, turbidity, Total Solid Suspended (TSS) and Total Dissolved Solid (TDS) on peat water. The result showed that organoleptic test given that peat water was not smell, turbidity removal was 95\%, color removal was 99,9\%, TSS was 97,5\% and TDS was 73,41\%. Based on parameter of Indonesian PERMENKES No. 492/MENKES/IV/2010 about characterized of drinking water quality and No. 81 year 2001 on the management of Water Quality and Control of Water Pollution showed that peat water can be utilized as cleaned water source
\end{abstract}

Keywords: coagulation-flocculation, milk package, poly aluminum chloride, peat water

\section{Introduction}

Currently, the need for Poly Aluminium Chloride (PAC) in Indonesia is obtained from abroad at high prices and requires complex equipment such as colorimetry speciation methods[1] baking process[2] and membrane reactors[3]. In fact, PAC can be made with a more simple method of partial hydrolysis method using $\mathrm{HCl}$ and $\mathrm{Na}_{2} \mathrm{CO}_{3}$ in polymerization process. The use of alternative raw materials derived from waste has been done before, namely by utilizing the industrial liquid waste of aluminum metal. [4] showed that PAC was successfully fabricated by reusing the aluminum metal contained in the wastewater to be a PAC forming monomer of $\mathrm{AlCl}_{3}$ and subsequently polymerized. Aluminum-based PAC coagulants from waste cans are successfully synthesized by partial hydrolysis method using $\mathrm{HCl}[5]$.

Utilization of cheap basic materials and simple techniques in recycling waste aluminum foil into coagulant is expected to reduce the amount of waste available. In this study, aluminum-based coagulant was made using aluminum foil waste using partial hydrolysis method using variation of mass sample with polymerization time 24, 48 and 72 hours. Then PAC was established based on SNI 06-3822-1995 and coagulant performance on peat water.

Peat water is one of the water sources in Indonesia. The area of peatland in Indonesia reaches 39.41 million hectares or $27 \%$ of the territory of Indonesia (excluding Irian Jaya). The distribution of the peat areas is found in Central and South Kalimantan, South Sumatra, Jambi and Riau Indonesia. Peat area for Riau Province about 4.1 million ha (Plantation Office of Riau Province, 2009). Communities inhabiting the peat lands are very difficult 
to get clean water because peat water is acidic and brown[6]. Therefore it is necessary to process peat water with PAC so it becomes feasible to drink.

\section{Details Experimental}

\subsection{Materials and Procedures}

This research consists of several stages. This research begins with collecting samples of milk packaging waste, making PAC by varying the polymerization time, characterization of functional groups by Fourier Transform Infra-red (FTIR) method, PAC characterization based on SNI 06-3822-1995 which includes measurement of specific gravity PAC, measurement of aluminum content, measurement of chloride content using argentometric method and $\mathrm{PAC} \mathrm{pH}$ measurement. PAC coagulation power testing of peat water with some odor, color, turbidity, TDS and TSS parameters, and comparing coagulation results with PERMENKES No. 492 / MENKES / PER / IV / 2010 on water quality requirements to be drunk and PP No. 81 year 2001 on the Management of Water Quality and Control of Water Pollution.

\subsection{Sample Preparation}

Aluminum-based milk waste is collected and cleaned. The polyethylene coating of the powdered milk packaging waste is removed, then the aluminum-based layer is cut into smaller sizes of approximately $1 \times 1 \mathrm{~cm}$ before being used as the base material for the manufacture of PAC coagulant.

\subsection{Synthesis of Poly Aluminum Chloride}

PAC coagulant of 3 types prepared A, B, C. Each coagulant was synthesized by chemical reaction, with the addition of $\mathrm{HCl} 33 \%$ and $\mathrm{Na}_{2} \mathrm{CO}_{3} 25 \%$ and varying the polymerization time.

TABLE I: The Composition and Timing of Polymerization of each type of Pac

\begin{tabular}{|c|c|c|c|c|c|}
\hline \multirow[b]{2}{*}{ No. } & \multirow{2}{*}{$\begin{array}{l}\text { Kind of } \\
\text { PAC }\end{array}$} & \multicolumn{3}{|c|}{ Composition } & \multirow{2}{*}{$\begin{array}{l}\text { Polimerization time } \\
\text { (hours) }\end{array}$} \\
\hline & & Weight (g) & $\begin{array}{l}\mathrm{HCl} 33 \% \\
\quad(\mathrm{~mL})\end{array}$ & $\begin{array}{c}\mathrm{Na}_{2} \mathrm{CO}_{3} 25 \% \\
(\mathrm{~mL})\end{array}$ & \\
\hline 1. & A & 2 & 18 & \multirow{3}{*}{$\begin{array}{l}\text { Addition to the } \\
\text { formation of little } \\
\text { sediment with not } \\
\text { bubbles }\end{array}$} & 24 \\
\hline 2. & B & 2 & 18 & & 48 \\
\hline 3 & $\mathrm{C}$ & 2 & 18 & & 72 \\
\hline
\end{tabular}

\subsection{Characterization of PAC Based on SNI 06-3822-1995}

Characterization of PAC based on SNI 06-3822-1995 includes measurement of type weights using pycnometer, $\mathrm{PAC} \mathrm{pH}$ measurement using $\mathrm{pH}$ meter, $\mathrm{Al}_{2} \mathrm{O}_{3}$ aluminum oxide content measurement and chloride content measurement using argentometric titration.

\subsection{Coagulation-Flocculation Process of PAC on Peat Water}

Peat water is taken as much as $500 \mathrm{~mL}$ and placed on 3 different erlenmeyer glass. Each PAC A, B, and C of $0.5 \mathrm{~mL}$ were added into the erlenmeyer glass containing the peat water. Fast stirring at $200 \mathrm{rpm}$ for 1 minute and stirring slowly at $50 \mathrm{rpm}$ for 15 minutes. Peat water is then allowed to stand for 30 minutes. Coagulation peat water is taken and analyzed with parameters such as turbidity, TSS, and TDS and then compare it with PERMENKES No.492/ MENKES/PER/IV/2010 on water quality requirements to be drunk. Then levels of TSS and TDS can be compared with PP No. 81year 2001 on the Management of Water Quality and Control of Water Pollution.

\subsection{Analysis of Parameters of Peat Water Samples}

The odor determination was done organoleptically (directly on samples to be analyzed) with 11 respondents. Color analysis was performed using a spectroquant pharo 300 instrument at a wavelength of $510 \mathrm{~nm}$. Determination of turbidity decline of peat water sample is done by using a turbidimeter tool in which the sample 
is in a state of free bubbles. The TSS reduction analysis is done by weighing the filter paper that has been used in peat water sampling. Weighing is done until it reaches a constant weight. TDS measurements of peat water were carried out by evaporation of heated peat water at $100^{\circ} \mathrm{C}$. The goblets used are weighed to a constant weight. Results of analysis of peat water parameters compared with PERMENKES No.492 / MENKES / PER / IV / 2010 on Water Quality Requirements.

\section{Results and Discussion}

\subsection{Synthesis, Establishment and Characterization of Poly Aluminum Chloride (PAC)}

PAC coagulant synthesis of aluminum-based dairy waste packaging forms aluminum chloride salt which is a Poly Aluminium Chloride monomer. The polymerization process of $\mathrm{PAC}$ is obtained by reaction of $\mathrm{AlCl} 3$ with $\mathrm{Na} 2 \mathrm{CO} 325 \%$. The reaction of PAC polymer formation can be seen in equation of bellow reaction

$$
\begin{aligned}
& 2 \mathrm{Al}+6 \mathrm{HCl} \longrightarrow 2 \mathrm{AlCl} 3+3 \mathrm{H} 2 \\
& 2 \mathrm{AlCl} 3+6 \mathrm{H} 2 \mathrm{O}+5 / 2 \mathrm{Na} 2 \mathrm{CO} 3 \longrightarrow \mathrm{Al} 2(\mathrm{OH}) 5 \mathrm{Cl}+5 \mathrm{NaCl}+5 / 2 \mathrm{H} 2 \mathrm{CO} 3+\mathrm{H} 2 \mathrm{O}
\end{aligned}
$$

The results of the underlying PAC product in accordance with the market is the stance that refers to the PAC quality requirements on SNI 06-3822-1995.

TABLE II: The Characterization of Pac Synthesis

\begin{tabular}{|l|l|l|l|l|l|l|}
\hline \multirow{2}{*}{ No. } & \multirow{2}{*}{$\begin{array}{l}\text { Sample } \\
\text { weight }(\mathrm{g})\end{array}$} & \multirow{2}{*}{$\begin{array}{l}\text { Polimerization } \\
\text { (hours) }\end{array}$} & \multicolumn{4}{|c|}{$\begin{array}{c}\text { Characterization of PAC synthesis } \\
\text { results }\end{array}$} \\
\cline { 4 - 8 } & & $\mathrm{pH}$ & $\begin{array}{l}\text { Density } \\
(\mathrm{g} / \mathrm{mL})\end{array}$ & $\begin{array}{l}\mathrm{Al}_{2} \\
\mathrm{O}_{3}\end{array}$ & $\mathrm{Cl}-$ \\
\hline 1. & 2 & 24 & 4,2 & 1,218 & 5,6 & 1,17 \\
\hline 2. & 2 & 48 & 4,1 & 1,238 & 4,45 & 1,24 \\
\hline 3. & 2 & 72 & 4.2 & 1,23 & 5,35 & 1,21 \\
\hline
\end{tabular}

In addition to PAC incorporation using SNI 06-3822-1995 standards, an analysis with FTIR was conducted to determine the type of bond and functional group[7]. The synthesis of PAC resulting from the synthesis of FTIR can be seen in Fig 1.

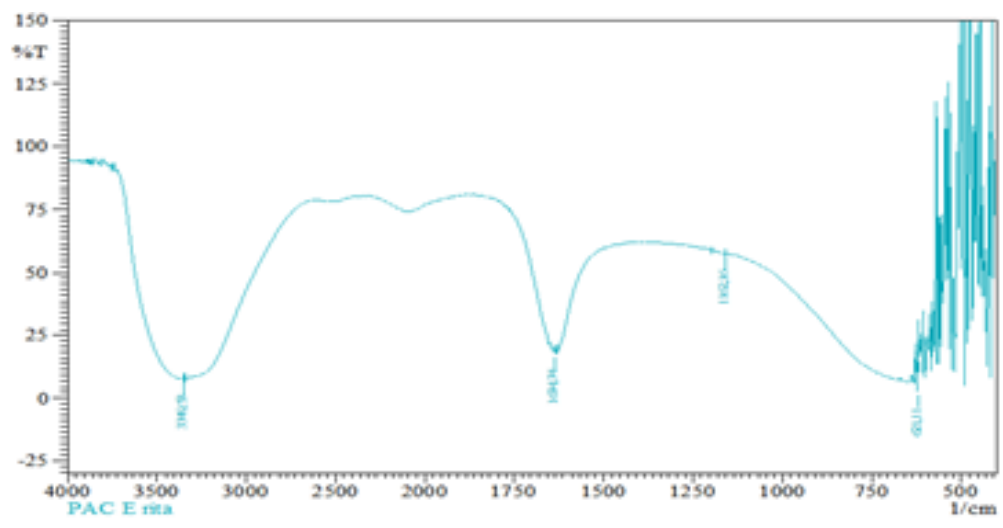

Fig.1: Characterization of PAC synthesis with FTIR

Coagulant PAC synthesis shows the presence of strain on consecutive wave numbers $3350 \mathrm{~cm}$ - indicating the absorption of binding $\mathrm{OH}$ groups[8]. The presence of inorganic compounds $(\mathrm{Al}$ and $\mathrm{Cl})$ is known by the absorption of wave numbers 1635,61 cm- and 1644,95 cm-[9]. The absorption band of PAC synthesis in 1166,02 $\mathrm{cm}$ - is the bending vibration of Al-OH. This is in accordance with research conducted by (10), the bend vibration of $\mathrm{Al}-\mathrm{OH} 2$ at the wave number of $1168.86 \mathrm{~cm}$. 


\subsection{Preliminary Analysis Peat Water Prior to Coagulation-Flocculation process}

Initial peat water analysis indicates that some parameters are beyond the minimum threshold of clean water quality based on PERMENKES No. 492 / MENKES / PER / IV / 2010 and PP No.82 Year 2001. For color shows intensity value of $1670 \mathrm{TCU}$. The greater value is due to the amount of dissolved organic matter content of $331 \mathrm{mg} / \mathrm{L}$. Turbidity on peat water is 128 NTU. High turbidity can be caused by the amount of mud, clay and organic acid as shown in Fig. 2 Turbidity associated with TSS, the higher the turbidity will be the higher the value of settled solids. Initial TSS value of peat water is $183 \mathrm{mg} / \mathrm{L}$. TDS in peat water comes from humus acid which is related to peat water color to brownish red. The presence of brownish red color can also come from cations such as $\mathrm{Fe}$ and $\mathrm{Mn}$ that dissolve in peat water. Initial TDS analysis of peat water for this parameter was $331 \mathrm{mg} / \mathrm{L}$. This value meets PERMENKES No.492/MENKES/PER/IV/ 2010 and Government Regulation No. 82 Year 2001.

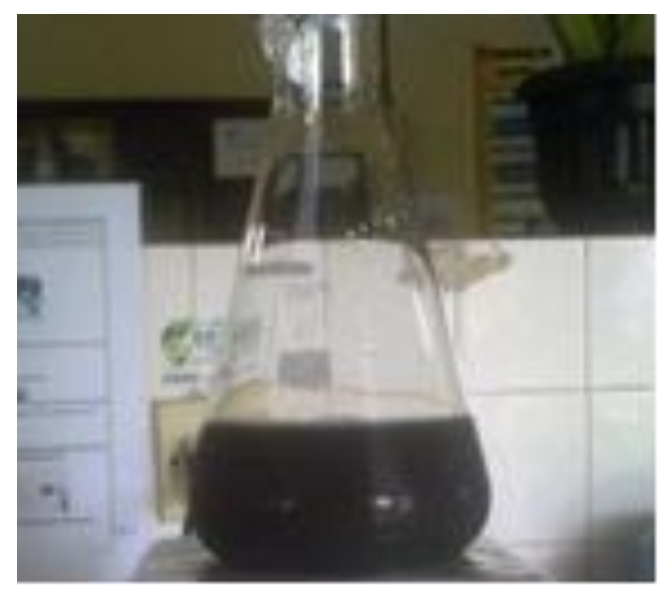

Fig. 2: Initial Peat water before coagulation-flocculation proces

\subsection{Analysis of Peat Water after Coagulation-Flocculation process}

Coagulation is a method of removing waste materials in the form of colloids by adding coagulants through rapid stirring in order to uniform the spread of chemicals through treated water. Then followed by the flocculation process, the formation of larger colloid flocs, through slow stirring.

\subsection{Analysis of Peat Water Odor after Coagulation-Flocculation process}

Analysis of odor after coagulation done organoleptically to 11 respondents shown in Tabel 3 . After being contacted with Poly Aluminum Chloride coagulant, 11 respondents stated no smell. This means that the addition of odorless coagulant to peat water after coagulation. The loss of odor in peat water is due to the organic compounds in peat water absorbed in the flocculation floc[11]. For the odor parameter to meet the PERMENKES standard No.492 / MENKES / PER / IV / 2010 on Water Quality Requirement and PP RI No. 82 of 2001 on the Management of Water Quality and Control of Water Pollution.

TABLE III: Results of Odor Analysis on Peat Water after Coagulation-Flocculation

\begin{tabular}{|c|c|c|c|c|c|}
\hline \multirow{2}{*}{ Coagulant } & \multicolumn{4}{|c|}{ Scale } & \multirow{2}{*}{ Conclusion } \\
\cline { 2 - 5 } & 0 & + & ++ & +++ & \\
\hline PAC A & 11 & - & - & - & Odorless \\
\hline PAC B & 11 & - & - & - & Odorless \\
\hline PAC C & 11 & - & - & - & Odorless \\
\hline
\end{tabular}

\subsection{Decrease of Turbidity and Color of Peat Water after Coagulation process}

Turbidity of peat water effect on water quality because peat water contained colloidal particles and other content. The turbidity removal in peat water is due to the ability of aluminum oxide to form floc as to clear peat 
water. This is already explained by (12) that the high content of aluminum oxide in PAC coagulant can eliminate the peat in peat water. The decrease of turbidity of peat water with 72 hours of polymerization time reached 98.92\%. This can be seen in Fig. 3 .

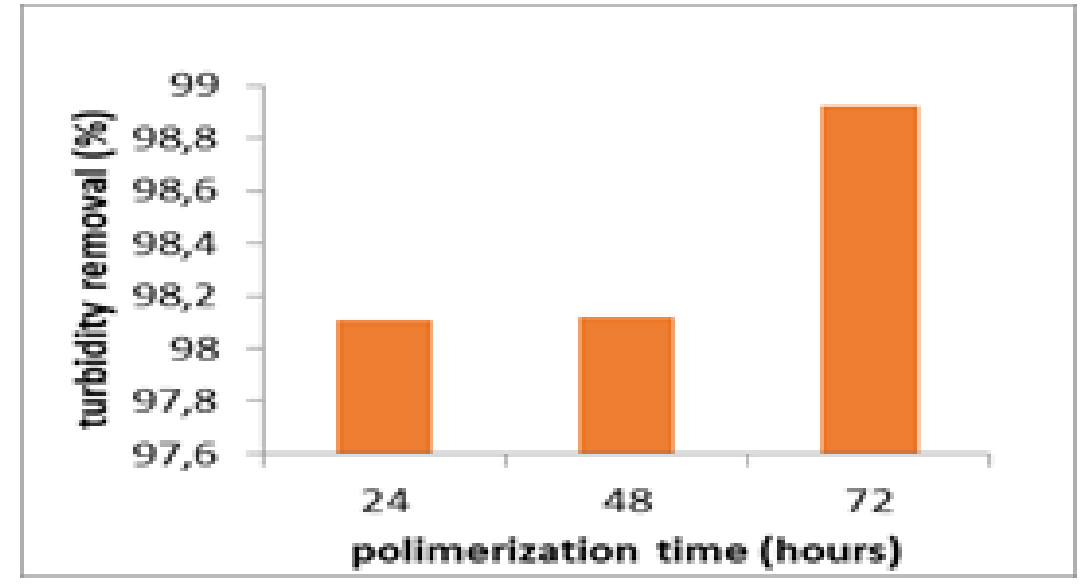

Fig. 3: Turbidity removal after coagulation-flocculation process

The intensity of peat water colour degradation after coagulation-flocculation process using PAC liquid coagulant reached $99.93 \%$. According to (13) the decrease in the intensity of colour on the surface water due to the positive charge of the coagulant that neutralizes the negative charge of colloidal particles to form floc. This decrease can be seen in Fig. 4

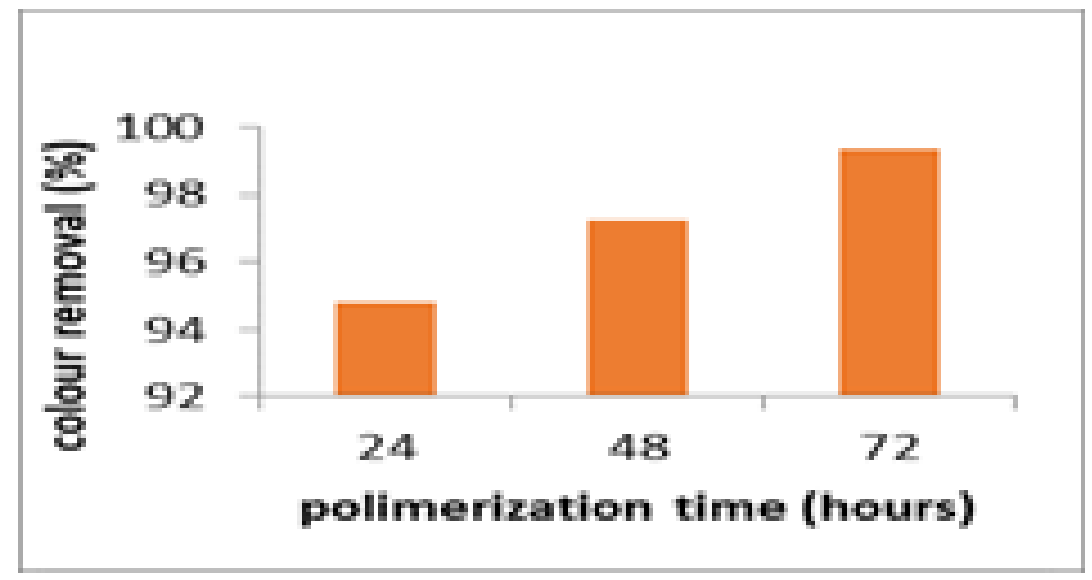

Fig. 4: Color removal after coagulation-flocculation process

\subsection{Decrease of Total Solid Suspended (TSS) and Total Dissolved Solid (TDS) of Peat Water After Coagulation-Flocculation Process}

Total Solid Suspended (TSS) is closely related to turbidity. Suspended substances in peat water are in the form of mud, sand, and organic and inorganic compounds. The decrease of peatland TSS after coagulation process reached $97.3 \%$ with 72 hours polymerization time. This decrease is due to suspended particles being bound by load restabilations on suspended substances [14]. The decrease of TDS peat water is caused by the interaction of coagulant cation which neutralizes the negative charge on the colloid surface so that the colloids also settle to form the floc in the coagulation process. The result of peatland TDS decrease after coagulationflocculation process reached $73.41 \%$. decrease of TSS and TDS of peat water can be seen in Fig. 5 dan 6. 


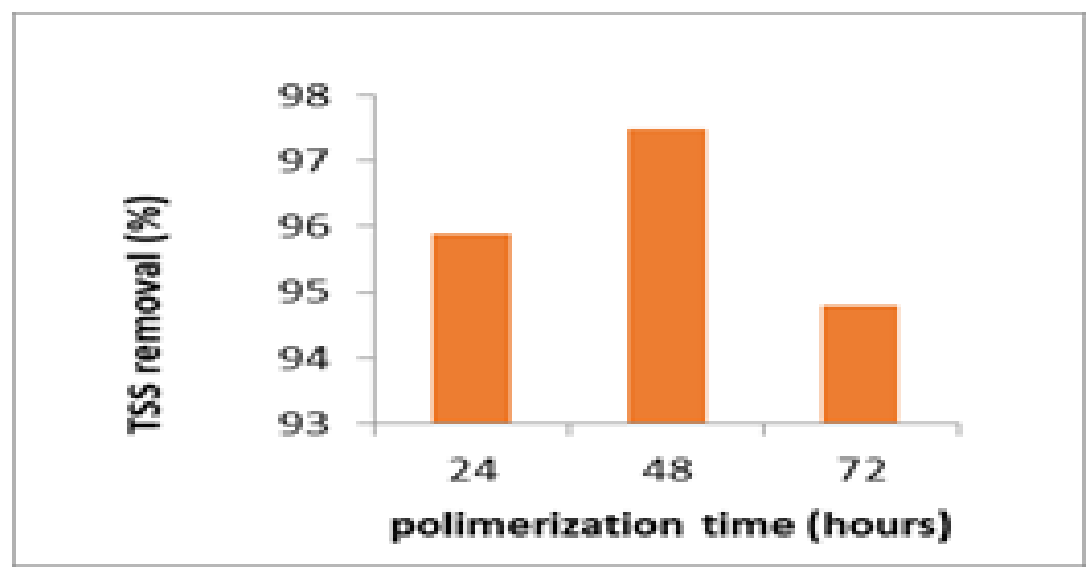

Fig.5: TSS removal after coagulation-floculation process

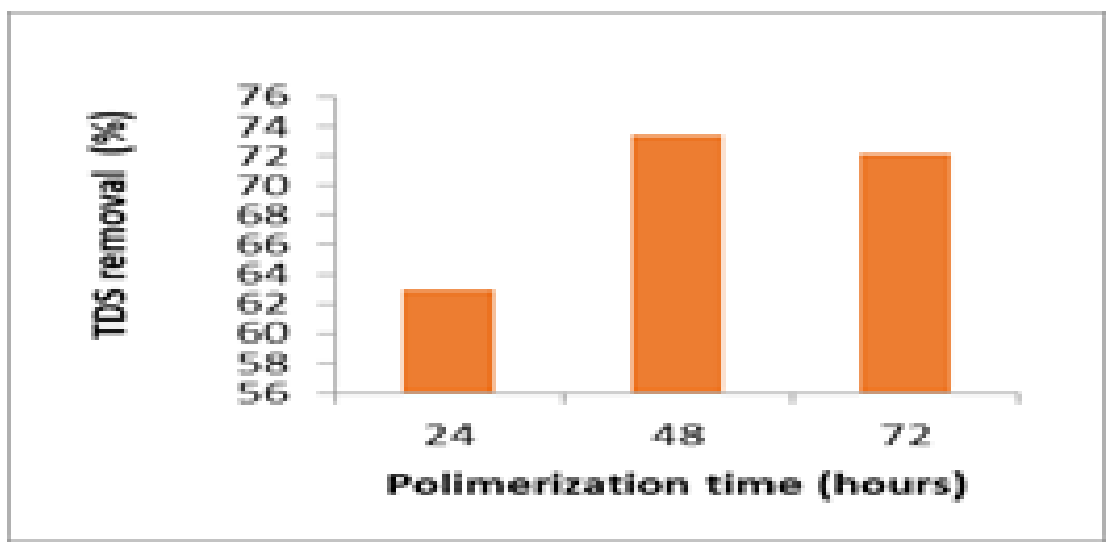

Fig. 6: TDS removal after coagulation-floculation process

\section{Acknowledgements}

The authors wishes to thanks to Indonesia Endowment Fund for Education (LPDP-RI) for financial support.The authors would also like to thank to lectures for providing guidance and encouragement during this study.

\section{References}

[1] Shen YH, Dempsey BA. Syhntesis and speciation of polyaluminium chloride for water treatment. J Environment Intl. 1998. 24:889-910. https://doi.org/10.1016/S0160-4120(98)00073-7

[2] Wang, L. K., Hung, Y. T. and Shamas, N. K. Physicochemical Treatment Processes. Handbook of Enviromental Engineering. Humana Press, Totova. 2005.

https://doi.org/10.1385/159259820x

[3] Fei H.E, Jia ZQ, Peng Y.L, Wang P.J, dan Liu Z.Z, A novel methode to syhntesize polyaluminium chloride (PAC) coagulant with high $\mathrm{Al}_{13}$ content. J. Environmental Management. 2004. 76 (2):143-147.

[4] Rinaldi, D.P. Utilization of industrial waste of aluminum metal as raw material of Poly aluminum Chloride in reducing turbidity of textile industry waste. Bogor Agricultural University, Bogor. 2009.

[5] Yuliansyah, A. Utilization of Canned Waste As Aluminum Based Coagulant Based Material. Jurnal of IPB , Bogor. 2013. 
[6] Pinem, J. A dan Fauzi. Utilization of Membrane Technology for Peat Water Treatment into Clean Water. Report of research. Faculty of engineering. Riau University, Pekanbaru. 2004.

[7] Goran SN. Fourier Transforms New Analytical Approaches And FTIR Strategies. Rijeka (CR): InTech.. 2011.

[8] Silverstein, R. M, Webster, F. X dan Kiemle, D. J. Spectrometric Identification of Organic Compounds. J Wiley, New York. 2005.

[9] United Kingdom. Ir Spectroscopy Software User'r Guide for Perkin Elmer Precisely. United Kingdom, New York. 2002.

[10] Tzoupanos ND, Zouboulisa AI, Tsoleridis CA. A systematic study for the characterization of a novel coagulant (polyaluminium silicate chloride). J Phy Eng. 2009. 342:30-39. doi:10.1016/j.colsurfa.2009.03.054 https://doi.org/10.1016/j.colsurfa.2009.03.054

[11] Syahroni, R. Peat Water Treatment Using Liquid Coagulants From Natural Clay Cengar. Jurnal JOM FMIPA. Riau University, Pekanbaru. 2014.

[12] Zoubulis AI, Tzoupanos N. Alternative cost-effective preparation method of polyaluminium chloride (PAC) coagulant agent: Characterization and comparative application forwater/wastewater treatment. J Desalination. 2010. 250:339344. doi:10.1016/j.desal.2009.09.053

https://doi.org/10.1016/j.desal.2009.09.053

[13] Amir, R. Determination of Optimum Aluminum Sulfate Dosage In Cileueur River Ciamis River Treatment and Mud Recirculation Treatment With Parameters of pH, Color, Turbidity and TSS. Jurnal of technique faculty, ITB. 2010.

[14] Reynold, T.D. Unit Operation and Processes in Environmental Engineering. Brooks/Cole Engineering Division. Monterey. California. 1996. 